\title{
Geldanamycin mediates the apoptosis of gastric carcinoma cells through inhibition of EphA2 protein expression
}

\author{
DA-HU WANG ${ }^{1 *}$, YU-JUN ZHANG ${ }^{2 *}$, SAN-BING ZHANG $^{3}$, \\ HUI LIU ${ }^{4}$, LIANG LIU ${ }^{5}$, FENG-LING LIU ${ }^{5}$ and JING ZUO 5 \\ ${ }^{1}$ Department of Dermatology, The Second Hospital of Hebei Medical University, Shijiazhuang, Hebei 050000; \\ ${ }^{2}$ Department of Pathology, Shijiazhuang People's Medical College, Shijiazhuang, Hebei 050091; \\ ${ }^{3}$ Department of Hand and Feet Surgery, The Third Hospital of Shijiazhuang City, Shijiazhuang, Hebei 050011; \\ ${ }^{4}$ Hebei Cancer Institute, Hebei Medical University, Shijiazhuang, Hebei 050012; ${ }^{5}$ Department of Oncology, \\ The Fourth Hospital of Hebei Medical University, Shijiazhuang, Hebei 050012, P.R. China
}

Received June 4, 2014; Accepted August 19, 2014

DOI: $10.3892 /$ or.2014.3542

\begin{abstract}
The aim of the present study was to investigate the role of EphA2 in the carcinogenesis and progression of gastric carcinoma. Moreover, we aimed to determine the effect of geldanamycin (GA), an inhibitor of Hsp90, on the proliferation and apoptosis of human gastric carcinoma cells. Gastric carcinoma tissues, paired adjacent mucosa and paired normal mucosa were obtained from resected surgical specimens of gastric carcinoma, and EphA2 mRNA and protein levels were assessed by RT-PCR, immunohistochemistry and western blot analysis. FCM was used to detect cell cycle distribution and apoptosis. MGC803 cell proliferation and apoptosis were assessed by MTT and FCM, respectively. We found that EphA2 protein was increased in the carcinogenesis of gastric epithelial cells. Proliferation index (PI) was significantly upregulated following an increase in EphA2 expression in gastric carcinoma compared with dysplasia and normal samples, and was notably correlated with grade and lymph node metastasis. Knockdown of EphA2 increased the apoptosis rate and decreased the PI of MGC803 cells, which overexpressed the EphA2 protein. GA inhibited the cell proliferation of MGC803 cells in a dose- and time-dependent manner and induced cell apoptosis. In addition, GA decreased the EphA2 protein expression in MGC803 cells. Overexpression of EphA2 inhibited cell growth, blocked cells in the G0/G1 stage and increased cell apoptosis induced by GA in MGC803 cells. However, knockdown of EphA2 in MGC803 cells increased the apoptosis ratio induced by GA. In conclusion, EphA2 overexpression is an important character-
\end{abstract}

Correspondence to: Professor Jing Zuo, Department of Oncology, The Fourth Hospital of Hebei Medical University, 12 Jiankang Road, Shijiazhuang, Hebei 050012, P.R. China

E-mail: susanliu2001@hotmail.com

${ }^{*}$ Contributed equally

Key words: gastric carcinoma, EphA2, geldanamycin, MGC803 cell line, cell proliferation, apoptosis istic in the carcinogenesis of gastric epithelial cells, followed by an increase in apoptosis and cell cycle arrest. Knockdown of EphA2 blocked MGC803 cell proliferation and induced cell apoptosis. In conclusion GA inhibits MGC803 cell proliferation and induces cell apoptosis by upregulating expression of EphA2.

\section{Introduction}

Gastric carcinoma is one of the most common malignant tumors. Recently, research has shown that the genesis and development of gastric carcinoma is a multi-step and multigene process. Therefore, it is extremely important to investigate the pathogenesis of gastric cancer and search for new targets of prevention and therapy and effective drugs for decreasing morbidity and mortality.

Receptor tyrosine kinases (RTKs) transmit extracellular signals to the nucleus, and then initiates a cascade of signaling events that modulate cellular responses. The erythropoietinproducing hepatocellular $(\mathrm{EPH})$ gene family represents the largest known family of receptor tyrosine kinases. EphA2 was the first gene identified with tyrosine kinase activity in the EPH family. In normal cells, EphA2 appears to be restricted to intercellular junctions between epithelial cells, where it binds ligands and anchors to the membrane of adjacent cells. It then initiates tyrosine kinases in the cytoplasm and participates in embryonic development, cell migration and vasiformation (1). A normal EphA2 expression signal weakens the Ras/MAPK cascade reaction, which is activated by PDEF, EGF, VEGF, and restrains cell growth. It then negatively regulates cellular adherin through breaking spot-adherin. EphA2 has been given more and more attention in carcinogenesis and development in recent years. EphA2 is overexpressed in many human cancers such as breast, colon, prostate and non-small cell lung cancer (NSCLC) (2-4), whose growth, transformation and metastasis correlate with EphA2 mutation, overexpression, abnormal location and (or) abnormal inactivation. Moreover, EphA2 is a new target for clinical diagnosis and therapy, while there is no exact experimental base for abormal expression of EphA2 in gastric carcinoma. 
Geldanamycin (GA), a benzoquinoid ansamycin antibiotic, targets heat shock protein 90 (Hsp90) (5). It is an inhibitor of Hsp90. Hsp90 is a group of highly conservative molecular chaperones, which is widely found in organisms. EphA2 is abnormally highly overexpressed in tumors, and its downstream proteins take part in key points of tumor progression. EphA2, as a member of the RTK family, is believed to be a downstream protein of Hsp90. Recently, GA has become a novel target for anticancer drug development due to its inhibition of cell proliferation and induction of apoptosis. However, whether GA suppresses cell proliferation of gastric carcinoma and the possible mechanisms remain undetermined.

Therefore, in this study, we detected the role of the expression of EphA2 in the carcinogenesis and progression of gastric carcinoma in order to explore the relationship between EphA2 expression and proliferation and apoptosis in gastric carcinoma. Furthermore, RNAi was used to silence EphA2 expression to investigate the precise effect of EphA2 on cell proliferation and apoptosis of gastric cancer cells. Moreover we determined the effect of GA, an inhibitor of Hsp90, on the proliferation and apoptosis of human gastric carcinoma MGC803 cells, which may elucidate the mechanism of the carcinogenesis and progression of gastric carcinoma as well.

\section{Materials and methods}

Reagents and antibodies. TRIzol reagent and Lipofectamine 2000 were obtained from Invitrogen (Carlsbad, CA, USA). Horseradish peroxidase (HRP) Affinipure goat anti-mouse/rabbit $\operatorname{IgG}(\mathrm{H}+\mathrm{L})$ and SP9000 were purchased from Zhongshan Golden Bridge Biotechnology Co., Ltd. (Beijing, China). FITC Affinipure goat anti-mouse IgG was from Jackson ImmunoResearch Co. The pCDNA3.1 vector and pCDNA3.1/EphA2 were obtained from Invitrogen Co. The rabbit anti-EphA2 antibodies were from Santa Cruz Biotechnology (Santa Cruz, CA, USA).

Clinical materials. Eighty-two cases of surgically resected primary gastric carcinoma tissues, paired adjacent mucosa (2-5 cm from the margin of the gastric carcinoma) and normal mucosa at the surgical margin (at least $5 \mathrm{~cm}$ from the margin of the gastric carcinoma and histologically proven) tissues collected between January and July 2007 at the Inpatient Department of the Fourth Hospital of Hebei Medical University were used in this study. These gastric carcinoma tissues included 30 cases of well-differentiated gastric carcinoma and 52 cases of moderately and poorly differentiated gastric carcinoma [superficial muscle invasive $(n=20)$, deep muscle invasive $(n=62)$, lymph node metastasis positive $(n=51)$, lymph node metastasis negative $(n=31)]$. Thirty cases were randomly chosen to detect EphA2 mRNA and protein expression [9 cases of well differentiated tissues and 21 cases of moderately and poorly differentiated tissues; superficial muscle invasive $(n=8)$, deep muscle invasive $(\mathrm{n}=22)$, lymph node metastasis positive $(\mathrm{n}=21)$, lymph node metastasis negative $(\mathrm{n}=9)]$. Experimental protocols were approved by the Institutional Human Care and Use Committee of Hebei Medical University.

Cell lines and treatment groups. Human gastric cancer cells (MGC803) were grown in humidified air with $5 \% \mathrm{CO}_{2}$ in an incubator at $37^{\circ} \mathrm{C}$ in RPMI-1640 supplemented with $10 \%$ fetal bovine serum, $100 \mu \mathrm{g} / \mathrm{ml}$ streptomycin and $100 \mathrm{U} / \mathrm{ml}$ penicillin. In order to investigate the effect of GA on cell proliferation, the cells were divided into 20, 40, 200, 400 and $2,000 \mathrm{nmol} / \mathrm{l}$ groups. In order to explore the mechanism of GA on apoptosis of MGC803 cells, the cells were divided into six groups: control, GA (200 nmol/l), GA + pYr-3.1-shNC, GA + pYr-3.1-shNC; GA + pcDNA3.1-EphA2-IRES-EGFP, and GA + pcDNA3.1-NC-IRES-EGFP; and were collected at $48 \mathrm{~h}$.

Immunohistochemistry and immunocytochemistry for detection of EphA2 protein. The tissues were fixed in $4 \%$ formaldehyde. Antigen recovery was performed using a microwave. The sections were incubated with primary antibodies against EphA2 (1:100) overnight at $4^{\circ} \mathrm{C}$. On the following day, the sections were incubated with polyperoxidase anti-mouse IgG at $37^{\circ} \mathrm{C}$, and finally stained with diaminobenzidine. The sections were imaged with an Olympus microscope. Positive staining of EphA2 protein was located in the cytoplasm or/and membrane of epithelial cells. The results were divided into 4 grades as previously described (6).

The cells were fixed in a $4 \%$ paraformaldehyde solution and permeabilized with $0.1 \%$ Triton X-100. Following incubation with anti-EphA2 (1:100; Santa Cruz) antibodies and the secondary antibody conjugated with HRP, the slices were stained with diaminobenzidine using the method introduced by Feng et al (7).

$R T-P C R$. Total RNA was extracted from gastric cancer tissues or MGC830 cells with TRIzol reagent according to the instructions of the manufacturer. Total RNA $(2 \mu \mathrm{g})$ was reverse transcribed into cDNA by AMV reverse transcriptase at $42^{\circ} \mathrm{C}$ for $1 \mathrm{~h}$ and then heated to $94^{\circ} \mathrm{C}$ for $5 \mathrm{~min}$ in a total reaction volume of $20 \mu \mathrm{l}$. The PCR condition used for EphA2 and the internal reference GAPDH was $94^{\circ} \mathrm{C}$ for 5 min followed by 33 cycles of $94^{\circ} \mathrm{C}$ for $45 \mathrm{sec}, 60^{\circ} \mathrm{C}$ for $45 \mathrm{sec}$ and $72^{\circ} \mathrm{C}$ for $45 \mathrm{sec}$, and $72^{\circ} \mathrm{C}$ for $7 \mathrm{~min}$. The specific primers were as follows: EphA2 sense, 5'-CCAAGTTCGCTGACATCGT-3 and antisense, 5'-GCCATGAAGTGCTCCGTAT-3'; GAPDH sense, 5'-ACCACAGTCCATGCCATCAC-3' and antisense, 5'-TCC ACCACCCTGTTGCTGTA-3'. The expected PCR products were 196 and 486 bp for EphA2 and GAPDH, respectively. The amplicons were analyzed by electrophoresis, imaged using UVI gel imaging system and quantified using Gel-Pro Analyzer 3.1 software. Expression levels of EphA2 were normalized to the internal reference GAPDH.

Total protein extraction and western blotting. Total protein extraction from the collected tissues and cultured cells was performed as described previously (8). The protein extracts were separated by $10 \%$ SDS-PAGE and then transferred to PVDF membranes. The membranes were incubated overnight at $4^{\circ} \mathrm{C}$ with anti-EphA2 (1:100; Santa Cruz) and $\beta$-actin (1:200; Santa Cruz) antibodies. Subsequently, the membranes were incubated with HRP-conjugated goat anti-rabbit $\operatorname{IgG}(1: 5,000)$ and then exposed to X-ray film using an enhanced chemiluminescence system (Pierce Biotechnology, Rockford, IL, USA). EphA2 protein expression was quantified by comparison with $\beta$-actin. 


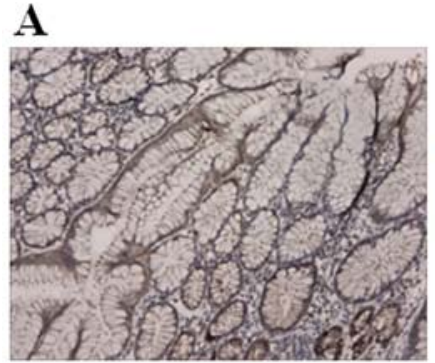

normal gastric mucosa

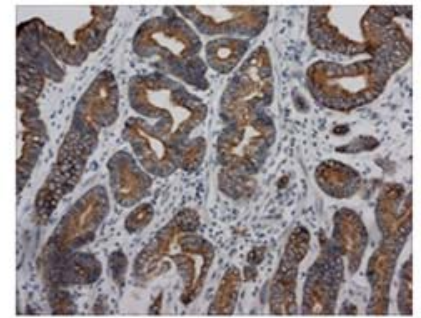

gastric carcinoma

\section{B}

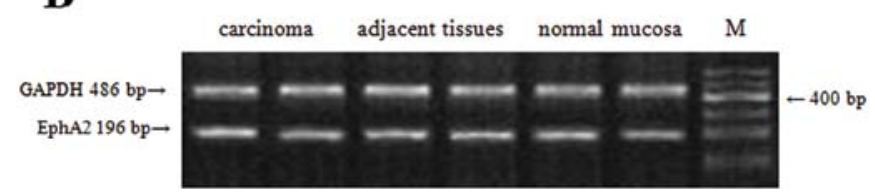

C
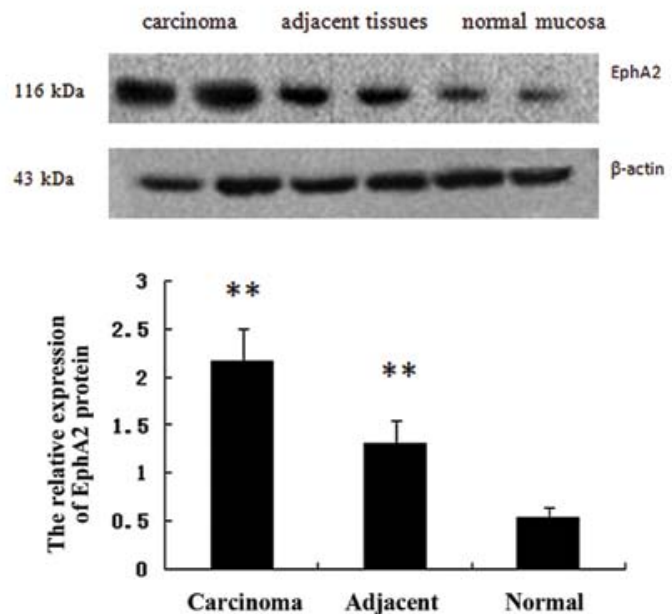

Figure 1. Upregulation of EphA2 protein in the carcinogenesis of gastric mucosa epithelial cells. (A) Immunohistochemical staining for EphA2 protein. Positive expression was noted in the cytoplasm and/or membrane of epithelial cells. (B) EphA2 mRNA expression was detected by RT-PCR. (C) As determined by western blot analysis, the EphA2 protein expression was increased in the carcinoma tissues.

Measurement of cell proliferation by MTT. MGC803 cells in a logarithmic phase were inoculated into a 96 -well plate with $1 \times 10^{5}$ cells in each well. Cell viability at $24 \mathrm{~h}$ was examined using the MTT method. OD $_{490 \mathrm{~nm}}$ values were detected in six duplicate wells and their averages were used to plot the growth curve and calculate the growth inhibition rate of each treatment using the following formula: Growth inhibition rate $(\mathrm{IR})=\mathrm{OD}_{490 \mathrm{~nm}}$ of the control group $-\mathrm{OD}_{490 \mathrm{~nm}}$ of the treatment group/OD $\mathrm{OD}_{490 \mathrm{~nm}}$ of the control group x $100 \%$.

Flow cytometric analysis. The tissues and the cell pellets treated by GA were fixed in $70 \%$ ethanol, and stained with $500 \mu \mathrm{g} / \mathrm{ml}$ propidium iodide (Sigma) containing 3 Kunitz units of RNase and $1 \%$ fetal bovine serum in PBS. Then, the stained cells were analyzed in an Epics-XLII flow cytometer (Beckman Coulter, Miami, FL, USA) and the number of the cells in each phase of the cell cycle was calculated using the ModFit LT cell cycle analysis program according to the manufacturer's instructions. The proliferation index (PI) represents
Table I. Expression of EphA2 in the different tissue groups (IHC).

\begin{tabular}{lcrrrr}
\hline Tissue groups & $\mathrm{n}$ & - & + & ++ & +++ \\
\hline Carcinoma & 82 & 6 & 16 & 28 & 32 \\
Adjacent & 82 & 35 & 26 & 19 & $2^{\text {a }}$ \\
Normal & 82 & 49 & 22 & 11 & $0^{\text {a }}$ \\
\hline
\end{tabular}

${ }^{\mathrm{a}} \mathrm{P}<0.01$, vs. carcinoma tissue group.

the number of proliferating cells and was calculated using the following equation: $\mathrm{PI}=\left(\mathrm{S}+\mathrm{G}_{2} \mathrm{M}\right) /\left(\mathrm{S}+\mathrm{G}_{2} \mathrm{M}+\mathrm{G}_{0} / \mathrm{G}_{1}\right) \times 100 \%$.

Transient transfection. The sh-EphA2 vector and negative control sh-Scramble vector were designed and produced by Invitrogen. The expression vector of EphA2 (pcDNA3.1EphA2-IRES-EGFP) and the control vector (pcDNA3.1-IRESEGFP) were designed and produced by the Beijing Fungenome Technology Co. (Beijing, China). Transient transfection of MGC803 cells was carried out using Lipofectamine 2000 according to the manufacturer's instructions. At $\sim 80 \%$ confluency, the cells were transfected with $2.0 \mu \mathrm{g}$ of vector DNA with $4 \mu \mathrm{l}$ of Lipofectamine 2000 in $2 \mathrm{ml}$ of serum-free RPMI-1640 medium. Six hours after the transfection, the cells were incubated for $48 \mathrm{~h}$ with normal RPMI-1640 medium containing $10 \%$ fetal bovine serum. Then, $200 \mathrm{nmol} / 1 \mathrm{GA}$ was added to the medium, and the cells were cultured for $48 \mathrm{~h}$. Subsequently, EphA2 expression, PI, cell cycle distribution and apoptosis were determined.

Statistical analysis. Data are expressed as mean \pm standard variation and were analyzed using SPSS 15.0 statistical software package. Differences between samples were tested using single factor analysis of variance and LSD method for multiple comparisons. A p-value $<0.05$ was considered as a significant difference. Before comparison, data homogeneity of variance was first examined using the $F$ test. In the case of heterogeneity of variance, the approximate variance F test/ Welch method was used.

\section{Results}

EphA2 protein expression is increased in the gastric carcinoma tissues and is positively correlated with the degree of differentiation and apoptosis. As shown in Fig. 1A and Table I, positive expression of EphA2 protein was noted in the cytoplasm and/or membrane and was higher in the carcinoma tissues than that in the adjacent and normal tissues $(\mathrm{P}<0.01)$. Moreover, the positive expression rate was higher in moderately and poorly differentiated tissues than that in the well-differentiated tissues $(\mathrm{P}<0.05)$. In addition, the expression of EphA2 in tumors with deep infiltration was higher than that in tumors with superficial layer invasion $(\mathrm{P}<0.05)$. Higher expression was noted in cases with lymph node metastasis than in non-lymph node metastasis ( $\mathrm{P}<0.05$, Tables II and III). There was no difference in EphA2 mRNA among the tissue groups as shown by RT-PCR ( $>>0.05$, Fig. 1B), while the 
Table II. Expression of EphA2 in gastric carcinoma tissues and the correlation with clinicopathological features (IHC).

\begin{tabular}{lcrrrrr}
\hline Features & $\mathrm{n}$ & - & + & ++ & +++ & P-value \\
\hline $\begin{array}{l}\text { Differentiation } \\
\quad \text { High }\end{array}$ & 30 & 3 & 9 & 12 & 6 & 0.019 \\
$\quad$ Moderate/low & 52 & 3 & 7 & 16 & 26 & \\
$\begin{array}{l}\text { Depth of invasion } \\
\quad\end{array}$ & & & & & \\
$\quad$ Superficial & 20 & 4 & 8 & 3 & 5 & 0.017 \\
$\quad$ Deep & 62 & 12 & 20 & 29 & 1 & \\
$\begin{array}{l}\text { Lymphatic } \\
\text { metastasis }\end{array}$ & & & & & & \\
$\quad$ Yes & 51 & 4 & 5 & 16 & 26 & 0.009 \\
$\quad$ No & 31 & 2 & 11 & 12 & 6 & \\
\hline
\end{tabular}
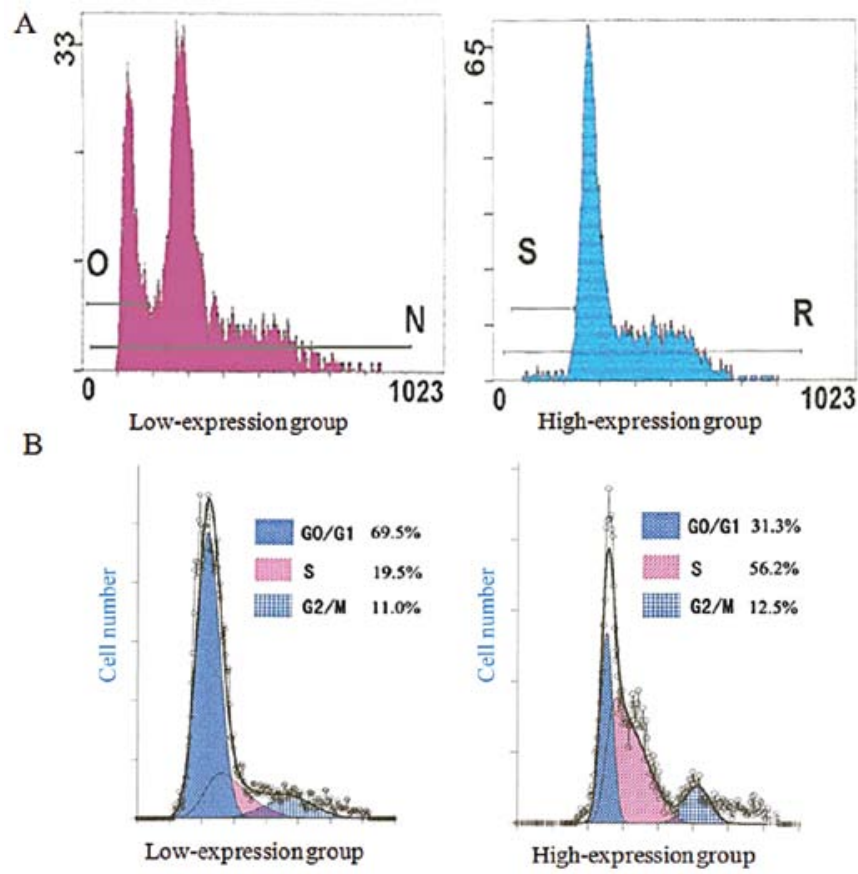

Figure 2. Overexpression of EphA2 is correlated with cell proliferation of gastric cancer cells. (A) Apoptosis was detected by FCM in the low-expression and high-expression groups. (B) FCM was used to detect the cell cycle distribution in the low-expression and high-expression groups.

results of the western blot analysis were identical with IHC and the EphA2 protein expression was increased in the gastric carcinoma tissues.

According to the results of IHC, the carcinoma cases were divided into two groups: EphA2 high-expression group $(++\sim+++)$ and EphA2 low-expression group (- +). The apoptosis rate was lower in the EphA2 high-expression group than that in the low-expression groups $(\mathrm{P}=0.018)$ and $\mathrm{PI}$ had a contrasting trend $(\mathrm{P}=0.002)$ as shown by FCM (Fig. 2 and Table IV).

Effect of RNAi silencing of EphA2 on the proliferation and apoptosis of human gastric carcinoma cell line MGC803. In

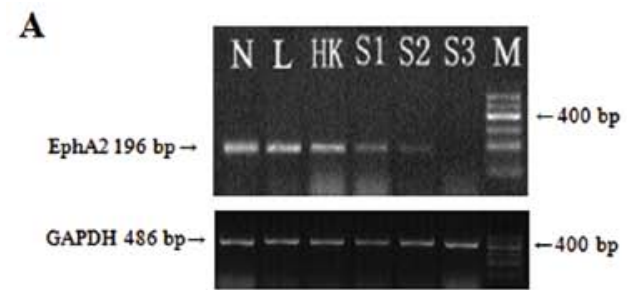

$\mathbf{B}$

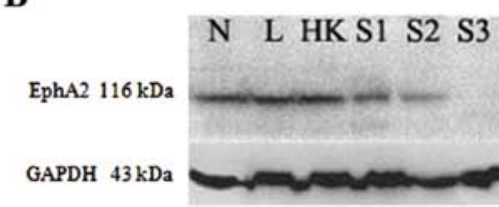

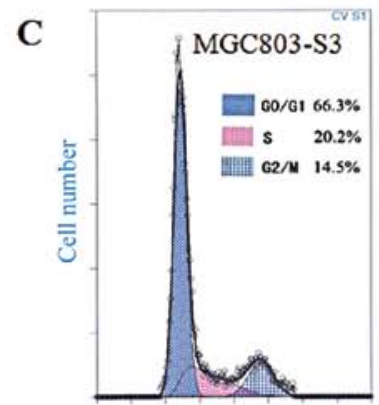

DNA content

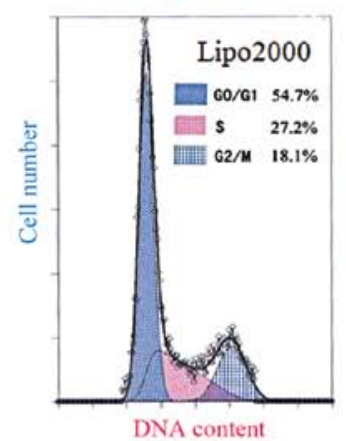

D
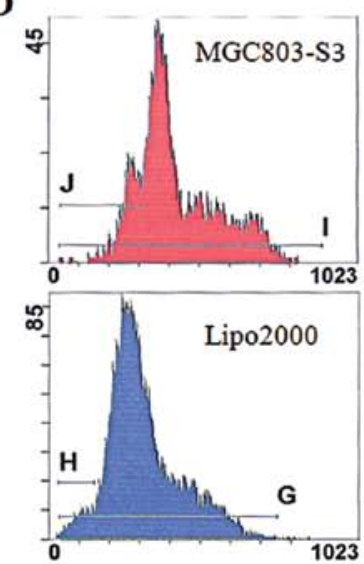

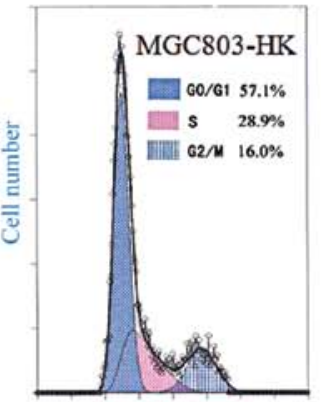

DNA content

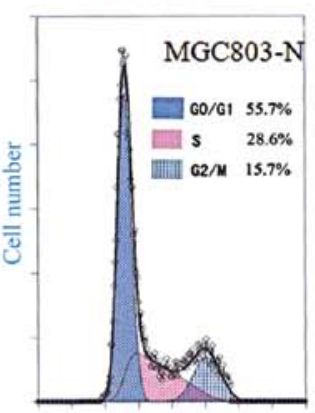

DNA conten
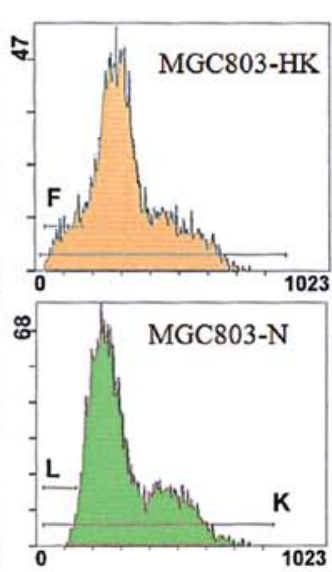

Figure 3. Silencing of EphA2 inhibits the proliferation and induces apoptosis. (A) EphA2 mRNA was detected by RT-PCR. (B) Western blot analysis was used to determine EphA2 protein. (C and D) FCM was used to detect the cell cycle distribution and cell apoptosis.

order to explore the precise effect of EphA2 on the cell proliferation and apoptosis of gastric cancer cells, the MGC803 
Table III. Relationship of EphA2 mRNA and protein expression (western blot analysis) with clinicopathological features of the gastric cancer cases.

\begin{tabular}{|c|c|c|c|c|c|}
\hline Features & $\mathrm{n}$ & $\begin{array}{c}\text { EphA2 mRNA } \\
(\text { mean } \pm \mathrm{SD})\end{array}$ & P-value & $\begin{array}{c}\text { EphA2 protein } \\
(\text { mean } \pm \mathrm{SD})\end{array}$ & P-value \\
\hline \multicolumn{6}{|c|}{ Tumor differentiation } \\
\hline High & 9 & $1.420 \pm 0.121$ & \multirow[t]{2}{*}{0.912} & $1.792 \pm 0.194$ & \multirow[t]{2}{*}{0.026} \\
\hline Moderate/low & 21 & $1.462 \pm 0.406$ & & $2.329 \pm 0.652$ & \\
\hline \multicolumn{6}{|c|}{ Depth of invasion } \\
\hline Superficial & 8 & $1.384 \pm 0.109$ & \multirow[t]{2}{*}{0.354} & $1.576 \pm 0.372$ & \multirow[t]{2}{*}{0.020} \\
\hline Deep & 22 & $1.473 \pm 0.242$ & & $2.383 \pm 0.890$ & \\
\hline \multicolumn{6}{|c|}{ Lymphatic metastasis } \\
\hline Yes & 21 & $1.450 \pm 0.369$ & \multirow[t]{2}{*}{0.978} & $2.201 \pm 0.787$ & \multirow[t]{2}{*}{0.596} \\
\hline No & 9 & $1.418 \pm 0.131$ & & $1.959 \pm 0.360$ & \\
\hline
\end{tabular}

Table IV. Apoptotic rate and proliferative index (PI) in the gastric carcinoma cases according to EphA2 expression.

\begin{tabular}{|c|c|c|c|c|c|}
\hline \multirow[b]{2}{*}{ EphA2 } & \multirow[b]{2}{*}{$\mathrm{n}$} & \multicolumn{2}{|c|}{ Apoptotic rate } & \multicolumn{2}{|c|}{ PI } \\
\hline & & Mean \pm SD $(\%)$ & P-value & Mean \pm SD $(\%)$ & P-value \\
\hline$-\sim+$ & 22 & $12.27 \pm 4.35$ & 0.018 & $41.83 \pm 19.44$ & 0.002 \\
\hline ++ +++ & 60 & $10.51 \pm 3.49$ & & $56.72 \pm 15.91$ & \\
\hline
\end{tabular}

Table V. Changes in the cell cycle distribute and proliferative index (PI) in the cell groups after transfection at $48 \mathrm{~h}$ (FCM).

\begin{tabular}{lcccc}
\hline Cells & $\mathrm{G}_{0} / \mathrm{G}_{1}$ & $\mathrm{~S}$ & $\mathrm{G}_{2} \mathrm{M}$ & PI \\
\hline MGC803-S3 & $62.70 \pm 2.39$ & $22.27 \pm 2.10$ & $15.03 \pm 0.55$ & $37.30 \pm 2.39$ \\
MGC803-HK & $57.40 \pm 0.98^{\mathrm{a}}$ & $26.10 \pm 1.47$ & $16.53 \pm 0.61$ & $42.60 \pm 0.98^{\mathrm{a}}$ \\
Lipo2000 & $54.30 \pm 1.73^{\mathrm{a}}$ & $29.93 \pm 3.74^{\mathrm{a}}$ & $15.77 \pm 2.35$ & $45.70 \pm 1.73^{\mathrm{a}}$ \\
MGC803-N & $56.33 \pm 1.18^{\mathrm{a}}$ & $27.77 \pm 3.33^{\mathrm{a}}$ & $15.90 \pm 2.21$ & $43.67 \pm 1.18^{\mathrm{a}}$ \\
\hline
\end{tabular}

${ }^{\text {aP }}<0.05$ vs. MGC803-S3. Data are expressed as mean $\pm \mathrm{SD}(\%)$.

cell line was used, which overexpressed the EphA2 protein. In addition, RNAi was used to knock down the expression of EphA2. As shown in Fig. 3A and B, MGC803 cells transfected with the sh-EphA2 vector showed low EphA2 mRNA and protein expression, particularly in the $\mathrm{S} 3$ vector group. On the contrary, no change in EphA2 protein expression was found between cells transfected with the blank control vector and the untransfected MGC803 cells.

FCM revealed that the number of cells in the $S$ phase decreased and the number of cells in the $G_{0} / G_{1}$ phase was increased. Therefore, the PI decreased following transfection of the MGC803 cells with the sh-EphA2 vector (Table V and Fig. 3C). Furthermore, silencing of EphA2 expression induced cell apoptosis (Table VI and Fig. 3D).

GA inhibits cell proliferation and induces cell apoptosis in the human gastric carcinoma cell line MGC803 and decreases EphA2 protein expression. The MTT results showed that GA inhibited the proliferation of MGC803 cells significantly in a time-dependent and dose-dependent manner and the highest inhibition rate reached $77.69 \pm 0.91 \%$; $\mathrm{IC}_{50}$ was $558.94 \mathrm{nmol} / 1$ after $48 \mathrm{~h}$ of GA treatment (Fig. 4A).

FCM analysis showed that the percentage of cells in the $\mathrm{S}$ phase was increased while the percentage of cells in the $\mathrm{G}_{2} / \mathrm{M}$ phase was decreased in the GA-stimulated cells compared with the control group, and the percentage of cells in the $\mathrm{S}$ phase was $36.35 \pm 3.04 \%$ in the control group, $45.00 \pm 1.41 \%$ in the middle-dose group, and $45.25 \pm 3.04 \%$ in the high-dose group, respectively. At same time, the percentage of cells in the $G_{0} / G_{1}$ phase increased (Fig. $4 B$ and Table VII). As shown in Table VIII, GA induced cell apoptosis of MGC803 cells in a dose-dependent manner $(\mathrm{P}<0.01)$. As shown in Fig. $4 \mathrm{C}$, GA treatment inhibited the expression of EphA2 protein.

In order to investigate whether GA induces MGC803 cell apoptosis through downregulation of EphA2 protein, transient transfection experiments were performed. Compared with 


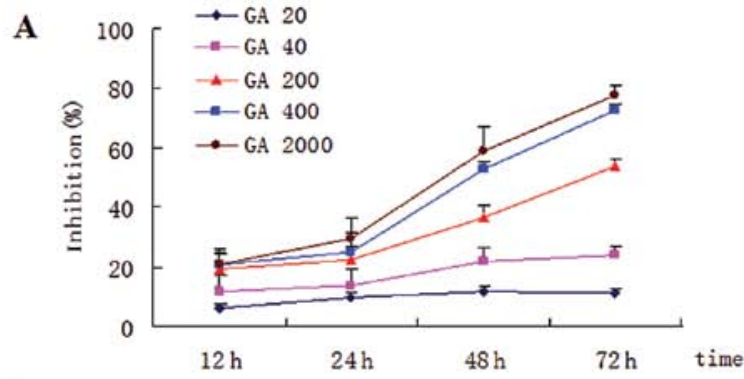

B

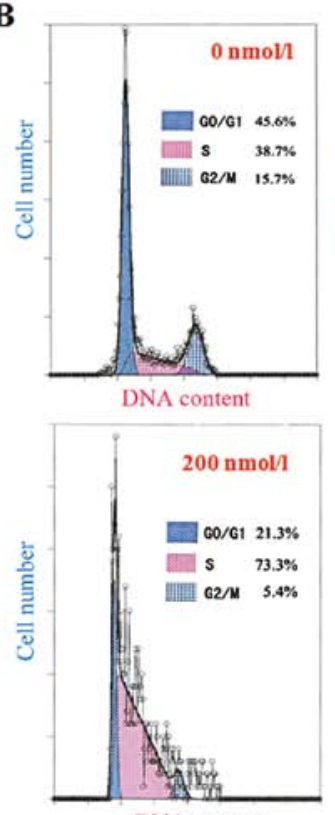

DNA content

C

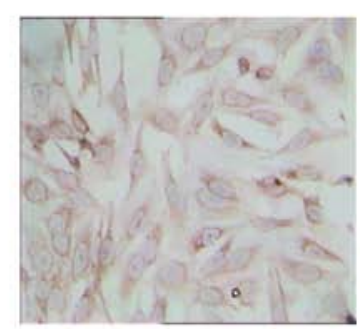

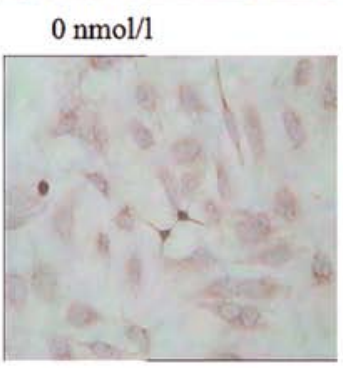

$200 \mathrm{nmol} / 1$
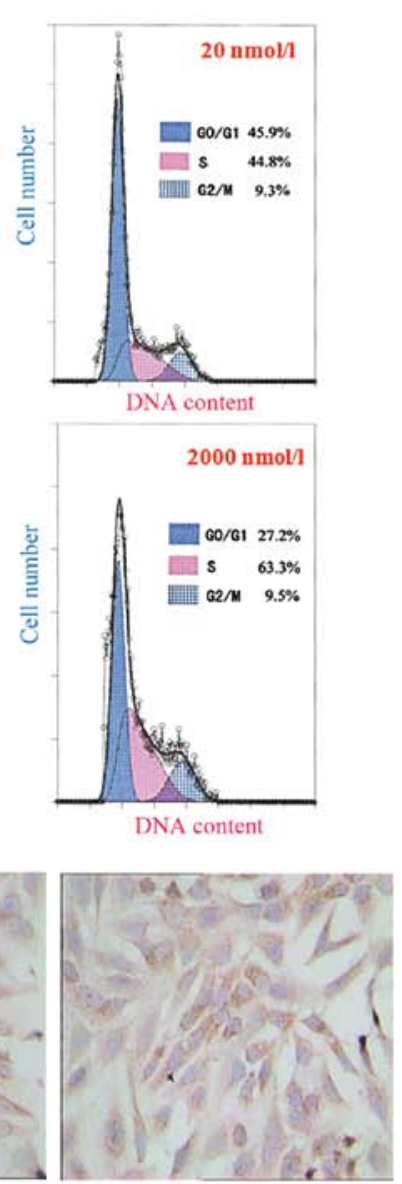

$20 \mathrm{nmol} / 1$

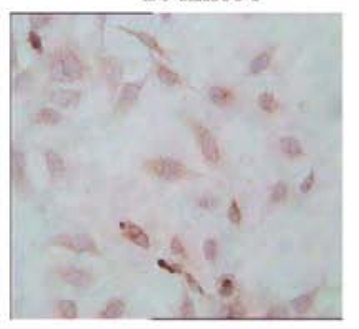

$2000 \mathrm{nmol} / \mathrm{l}$
Figure 4. Geldanamycin (GA) inhibits MGC803 cell proliferation and induces cell apoptosis, followed by downregulation of EphA2 protein. (A) MTT assay was used to detect the effect of GA on cell proliferation of MGC803 cells. GA inhibited cell proliferation. (B) GA decreased the percentage of cells in the $S$ phase as determined by FCM. (C) GA decreased the EphA2 protein expression in a dose-dependent manner.

the control group, pcDNA3.1-EphA2-IRES-EGFP effectively upregulated the EphA2 protein and mRNA levels in the MGC803 cells by 2.3 and 2.5-fold. As detected by FCM, GA increased the apoptosis ratio of MGC803 cells; however, the
Table VI. Apoptosis rate of the 4 cell groups after transfection at $48 \mathrm{~h}(\mathrm{FCM})$.

\begin{tabular}{lcr}
\hline Cells & $\begin{array}{c}\text { Apoptosis rate } \\
(\text { Mean } \pm \text { SD) }\end{array}$ & P-value \\
\hline MGC803-S3 & $19.53 \pm 0.80$ & 0.0001 \\
MGC803-HK & $11.05 \pm 1.34^{\mathrm{a}, \mathrm{b}}$ & \\
Lipo2000 & $9.83 \pm 0.44^{\mathrm{a}, \mathrm{b}}$ & \\
MGC803-N & $2.28 \pm 0.61^{\mathrm{a}}$ & \\
\hline
\end{tabular}

${ }^{\mathrm{a}} \mathrm{P}<0.01$, vs. MGC803-S3; ${ }^{\mathrm{P}}<0.01$ vs. MGC803-N

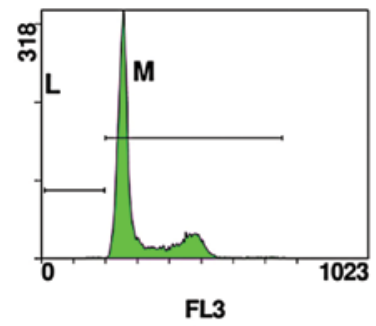

control group

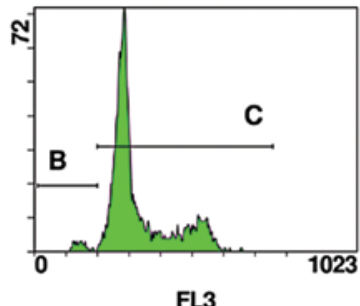

$\mathrm{GA}+\mathrm{EphA} 2$ vector

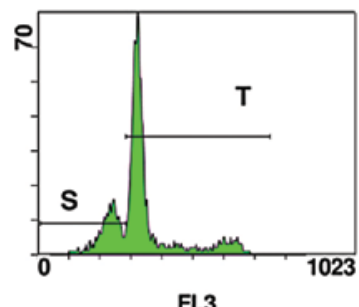

GA group

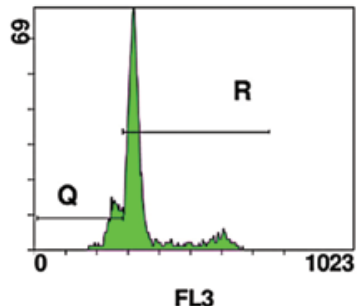

$\mathrm{GA}+\mathrm{EphA} 2$ siRNA
Figure 5. Effect of geldanamycin (GA) on cell apoptosis of MGC803 cells by FCM. The apoptosis rate was decreased in the GA+EphA2 vector group and increased in the GA+EphA2siRNA group compared with the GA group $(\mathrm{P}<0.01)$.

apoptosis ratio in the $\mathrm{GA}+\mathrm{EphA} 2$ vector group was decreased compared with the GA group. Importantly, knockdown of EphA2 expression increased the apoptosis ratio induced by GA in the MGC803 cells (Fig. 5).

\section{Discussion}

EphA2 is overexpressed in a variety of human malignancies, such as breast, colon, ovarian and pancreatic (9-13). EphA2 mediates angiogenesis, tumor growth, invasion and metastasis $(9,14-16)$ and its expression level is correlated with patient prognosis (17-21). Although the kinase domain is necessary for EphA2-driven cell migration and tumorigenicity (22), the outcome of ligand-dependent receptor phosphorylation is controversial. Furthermore, the activation of oncogenic signaling pathways further disrupts the delicate balance of EphA2 bi-directional signaling (23). Our results showed that EphA2 protein expression was increased in the gastric carcinoma tissues and was positively correlated with the histologic degree of differentiation. In addition, apoptosis rate was 
Table VII. Effect of geldanamycin (GA) on MGC803 cell cycle distribution as assayed by FCM.

\begin{tabular}{|c|c|c|c|c|}
\hline $\begin{array}{l}\text { Treatment } \\
\text { groups }\end{array}$ & $\begin{array}{l}\text { Concentration } \\
(\mathrm{nmol} / \mathrm{l})\end{array}$ & $\mathrm{G}_{0} / \mathrm{G}_{1}$ & $\mathrm{~S}$ & $\mathrm{G}_{2} / \mathrm{M}$ \\
\hline A (control) & 0 & $34.00 \pm 1.56$ & $36.35 \pm 3.04$ & $29.65 \pm 4.60$ \\
\hline B & 20 & $39.85 \pm 3.89$ & $36.65 \pm 2.19$ & $23.50 \pm 1.70$ \\
\hline $\mathrm{C}$ & 200 & $42.50 \pm 2.12$ & $45.00 \pm 1.41^{\mathrm{a}}$ & $12.57 \pm 1.71^{\mathrm{a}}$ \\
\hline D & 2,000 & $49.20 \pm 4.81^{\mathrm{a}}$ & $45.25 \pm 3.04^{\mathrm{a}}$ & $5.55 \pm 2.19^{\mathrm{a}}$ \\
\hline
\end{tabular}

${ }^{\mathrm{a}} \mathrm{P}<0.05$ vs. A, B. Data are expressed as the mean $\pm \mathrm{SD}(\%)$.

Table VIII. Influence of geldanamycin (GA) on the apoptosis of MGC-803 cells (FCM).

\begin{tabular}{lccc}
\hline $\begin{array}{l}\text { Treatment } \\
\text { groups }\end{array}$ & $\begin{array}{c}\text { Concentration } \\
(\mathrm{nmol} / \mathrm{l})\end{array}$ & Apoptotic rate (\%) & P-value \\
\hline A (control) & 0 & $1.76 \pm 0.36$ & 0.002 \\
B & 20 & $5.94 \pm 1.25^{\mathrm{a}}$ & \\
C & 200 & $15.44 \pm 6.48^{\mathrm{b}}$ & \\
D & 2,000 & $26.91 \pm 3.30^{\mathrm{b}}$ & \\
\hline
\end{tabular}

${ }^{\mathrm{a}} \mathrm{P}<0.05$ vs. $\mathrm{A} ;{ }^{\mathrm{b}} \mathrm{P}<0.01$ vs. A. Data are expressed as mean $\pm \mathrm{SD}$.

higher in the EphA2 high-expression group than that in the low-expression group while PI had an inverse trend, which suggests that EphA2 plays an important role in angiogenesis of gastric carcinoma, especially related with abnormal growth of gastric carcinoma cells.

RNAi has become an important method in tumor research (24). In order to further investigate whether EphA2 is involved in the cell proliferation or cell apoptosis of gastric cancer cells, RNAi method was used to knock down the expression of EphA2. Moreover, EphA2 knockdown inhibited MGC803 cell growth, and blocked cells in the $\mathrm{G}_{0} / \mathrm{G}_{1}$ stage, inducing apoptosis, suggesting that silencing of EphA2 inhibits tumorigenesis and development possibly through cell cycle arrest and induction of cell apoptosis.

GA is a benzoquinone ansamycin antibiotic and a potent tyrosine kinase inhibitor that was first isolated from Streptomyces hygrocopicus in 1970. GA is also known as a potent inhibitor of Hsp90 (25). Research has shown that GA inhibits cell growth in many types of cancers $(26,27)$. However, it is unknown whether or not GA inhibits cell growth of gastric cancer. In the present study, we found that GA inhibited the cell proliferation of MGC803 cells, arrested the cell cycle and induced cell apoptosis in a dose- and time-dependent manner, which suggests that GA has an anticancer effect on gastric cancer.

In order to investigate whether GA inhibited cell growth through inhibition of EphA2 expression, we detected the effect of EphA2 by GA and analyzed the correlation between EphA2 expression and apoptosis. The results showed that GA decreased the expression of EphA2 protein and EphA2 expression was negatively correlated with cell apoptosis. Overexpression of EphA2 inhibited cell apoptosis induced by GA and knockdown of EphA2 protein increased the apoptosis rate induced by GA in MGC803 cells. From the above results, we believe that GA inhibits cell proliferation and induces apoptosis partly through inhibition of EphA2 protein expression.

In summary, our data demonstrated that EphA2 overexpression plays an important role in the carcinogenesis of gastric epithelial cells, with a decrease in apoptosis and cell cycle arrest. Knockdown of EphA2 blocked MGC803 cell proliferation and inducd cell apoptosis. GA inhibited MGC803 cell proliferation and induced cell apoptosis by upregulating expression of EphA2. These findings suggest that EphA2 may be a new target for preventing gastric carcinogenesis and treating gastric carcinoma. However, further studies are needed to examine the precise role of EphA2 in the pathogenesis of gastric cancer.

\section{Acknowledgements}

This research was supported by the Hebei Natural Science Foundation (H2013206446).

\section{References}

1. Nakamoto M and Bergemann AD: Diverse roles for Eph family of receptor tyrosine kinases in carcinogenesis. Microsc Res Tech 59: 58-67, 2002.

2. Fang WB, Brantley-Sieders DM, Parker MA, Reith AD and Chen J: A kinase-dependent role for EphA2 receptor in promoting tumor growth and metastasis. Oncogene 24: 7859-7868, 2005.

3. Miyazaki T, Kato H, Fukuchi M, Nakajima M and Kuwano H: EphA2 overexpression correlates with poor prognosis in esophageal squamous cell carcinoma. Int J Cancer 103: 657-663, 2003.

4. Orsulic S and Kemler R: Expression of Eph receptors and ephrins is differentially regulated by E-cadherin. J Cell Sci 113: 1793-1802, 2000.

5. Trojandt S, Reske-Kunz AB and Bros M: Geldanamycinmediated inhibition of heat shock protein 90 partially activates dendritic cells, but interferes with their full maturation, accompanied by impaired upregulation of RelB. J Exp Clin Cancer Res 33: 16, 2014.

6. Zeng G, Hu Z, Kinch MS, Pan CX, Flockhart DA, Kao C, Gardner TA, Zhang S, Li L, Baldridge LA, Koch MO, Ulbright TM, Eble JN and Cheng L: High-level expression of EphA2 receptor tyrosine kinase in prostatic intraepithelial neoplasia. Am J Patho1 163: 2271-2276, 2003.

7. Feng X, Hao J, Liu Q, Yang L, Lv X, Zhang Y, Xing L, Xu N and Liu S: HMGB1 mediates IFN- $\gamma$-induced cell proliferation in MMC cells through regulation of cyclin D1/CDK4/p16 pathway. J Cell Biochem 113: 2009-2019, 2012. 
8. Hao J, Zhang YJ, Lv X, Xu N, Liu QJ, Zhao S, Feng XJ, Xing LL, Kang PP, Li GY and Liu SX: IFN- $\gamma$ induces lipogenesis in mouse mesangial cells via the JAK2/STAT1 pathway. Am J Physiol Cell Physiol 304: c760-c767, 2013.

9. Dodelet VC and Pasquale EB: Eph receptors and ephrin ligands: embryogenesis to tumorigenesis. Oncogene 19: 5614-5619, 2000.

10. Duxbury MS, Ito H, Zinner MJ, Ashley SW and Whang EE: Ligation of EphA2 by Ephrin A1-Fc inhibits pancreatic adenocarcinoma cellular invasiveness. Biochem Biophys Res Commun 320: 1096-1102, 2004

11. Thaker PH, Deavers M, Celestino J, Thornton A, Fletcher MS Landen CN, Kinch MS, Kiener PA and Sood AK: EphA2 expression is associated with aggressive features in ovarian carcinoma. Clin Cancer Res 10: 5145-5150, 2004.

12. Wykosky J, Gibo DM, Stanton C and Debinski W: EphA2 as a novel molecular marker and target in glioblastoma multiforme. Mol Cancer Res 3: 541-551, 2005.

13. Liu F, Park PJ, Lai W, Maher E, Chakravarti A, Durso L, Jiang X Yu Y, Brosius A, Thomas M, Chin L, Brennan C, DePinho RA, Kohane I, Carroll RS, Black PM and Johnson MD: A genomewide screen reveals functional gene clusters in the cancer genome and identifies EphA2 as a mitogen in glioblastoma. Cancer Res 66: 10815-10823, 2006.

14. Zelinski DP, Zantek ND, Stewart JC, Irizarry AR and Kinch MS: EphA2 overexpression causes tumorigenesis of mammary epithelial cells. Cancer Res 61: 2301-2306, 2001.

15. Hess AR, Seftor EA, Gruman LM, Kinch MS, Seftor RE and Hendrix MJ: VE-cadherin regulates EphA2 in aggressive melanoma cells through a novel signaling pathway: implications for vasculogenic mimicry. Cancer Biol Ther 5: 228-233, 2006.

16. Brantley-Sieders DM, Zhuang G, Hicks D, Fang WB Hwang Y, Cates JM, Coffman K, Jackson D, Bruckheimer E, Muraoka-Cook RS and Chen J: The receptor tyrosine kinase EphA2 promotes mammary adenocarcinoma tumorigenesis and metastatic progression in mice by amplifying ErbB2 signaling. J Clin Invest 118: 64-78, 2008.

17. Fox BP and Kandpal RP: Invasiveness of breast carcinoma cells and transcript profile: Eph receptors and ephrin ligands as molecular markers of potential diagnostic and prognostic application. Biochem Biophys Res Commun 318: 882-892, 2004.
18. Herrem CJ, Tatsumi T, Olson KS, Shirai K, Finke JH, Bukowski RM, Zhou M, Richmond AL, Derweesh I, Kinch MS and Storkus WJ: Expression of EphA2 is prognostic of diseasefree interval and overall survival in surgically treated patients with renal cell carcinoma. Clin Cancer Res 11: 226-231, 2005.

19. Merritt WM, Thaker PH, Landen CN Jr, Deavers MT, Fletcher MS, Lin YG, Han LY, Kamat AA, Schmandt R, Gershenson DM, Kinch MS and Sood AK: Analysis of EphA2 expression and mutant p53 in ovarian carcinoma. Cancer Biol Ther 5: 1357-1360, 2006.

20. Abraham S, Knapp DW, Cheng L, Snyder PW, Mittal SK, Bangari DS, Kinch M, Wu L, Dhariwal J and Mohammed SI: Expression of EphA2 and Ephrin A-1 in carcinoma of the urinary bladder. Clin Cancer Res 12: 353-360, 2006.

21. Larsen AB, Pedersen MW, Stockhausen MT, Grandal MV, van Deurs B and Poulsen HS: Activation of the EGFR gene target EphA2 inhibits epidermal growth factor-induced cancer cell motility. Mol Cancer Res 5: 283-293, 2007.

22. Fang WB, Brantley-Sieders DM, Parker MA, Reith AD and Chen J: A kinase-dependent role for EphA2 receptor in promoting tumor growth and metastasis. Oncogene 24: 7859-7868, 2005.

23. Carles-Kinch K, Kilpatrick KE, Stewart JC and Kinch MS: Antibody targeting of the EphA2 tyrosine kinase inhibits malignant cell behavior. Cancer Res 62: 2840-2847, 2002.

24. Zantek ND, Azimi M, Fedor-Chaiken M, Wang B, Brackenbury R and Kinch MS: E-cadherin regulates the function of the EphA2 receptor tyrosine kinase. Cell Growth Differ 10: 629-638, 1999.

25. Macrae M, Neve RM, Rodriguez-Viciana P, Haqq C, Yeh J, Chen C, Gray JW and McCormick F: A conditional feedback loop regulates Ras activity through EphA2. Cancer Cell 8: 111-118, 2005.

26. Ui T, Morishima K, Saito S, Sakuma Y, Fujii H, Hosoya Y, Ishikawa S, Aburatani H, Fukayama M, Niki T and Yasuda Y: The HSP90 inhibitor 17-N-allylamino-17-demethoxy geldanamycin (17-AAG) synergizes with cisplatin and induces apoptosis in cisplatin-resistant esophageal squamous cell carcinoma cell lines via the Akt/XIAP pathway. Oncol Rep 31: 619-24, 2014.

27. Jilani K, Qadri SM and Lang F: Geldanamycin-induced phosphatidylserine translocation in the erythrocyte membrane. Cell Physiol Biochem 32: 1600-1609, 2013. 